\title{
Relationship between Trade Openness, Financial Development and Economic Growth of Nepal: Evidence from a Developing Country
}

\author{
Shreezal G.C.
}

Scholar, Central Department of Economics, Tribhuvan University, Nepal (shreezalgc@gmail.com)

Received: 10 August, 2020 Revised: 22 October, 2020 Accepted: 18 November, 2020 Published: 15 December, 2020

How to cite this paper:

G.C., S. (2020). Relationship between trade openness, financial development and economic growth of Nepal: evidence from a developing country. Quest Journal of Management and Social Sciences, 2(2), 206-224.

Copyright (C) 2020 by authors and Quest Journal of Management and Social Sciences.

This work is licensed under a Creative Commons Attribution-Non Commercial-No Derivatives 4.0 International License.

https://creativecommons.org/ licenses/by-nc-nd/4.0/

\begin{abstract}
Background: Capital investment, financial and technological developments are essential drivers for the economic growth of developing countries like Nepal. These factors, directly and indirectly, contribute to the growth of the country. Technological factors such as FDI and trade allow technology and knowledge transfers to Nepal along with foreign investments, goods and services. The financial sector encourages investors by providing loans that further generates investment in the country. Similarly, the development of human capital further increases labor productivity. Nepal, being a developing country, lacks advanced infrastructure and technology, that are vital for pushing the economic growth in the country.
\end{abstract}

Objective: This paper examined the effect of capital, labor, foreign direct investment, financial development and trade on the economic growth of Nepal using the endogenous growth model.

Methods: The study employed the ARDL bounds testing approach to test the long-run relationships introducing an error correction model to estimate both short and long-term relationships among the variables. The TY non-granger causality test was used to ensure robustness and check the direction of causality.

Results: The results showed that gross fixed capital formation, population and financial development were significant and induced positive economic growth in the long run at a $1 \%$ level of significance whereas, the impact of FDI on economic growth was negative and significant at $1 \%$.

Conclusions: The study concludes that an increase in gross fixed capital formation, population and broad money supply positively impacts the economic growth of Nepal. However, technological factors such as FDI and trade do not adequately explain the economic growth due to low FDI inflows, political instability, poor infrastructure and import dependency.

Implications: The study emphasized domestic investment and financial development of the country as they were found to be highly significant in the long run. Also, the human capital of the country should be developed by providing education and training as the population was found to be highly significant. The study also indicated that Nepal should push export as its share in the trade is very less. Moreover, policies such as legal reforms, incentives to foreign investors and infrastructural development to attract FDIs in Nepal should be formulated.

Keywords: GDP, GFCF, Trade, FDI, ARDL

JEL Classification: O11, O4, O40 


\section{Introduction}

Trade liberalization and globalization have opened up a common arena for all the countries across the world for trading goods, making foreign investments and transferring technology. After the 1970s, international trade expanded all over the world as most of the developing and transitioning countries achieved liberalization in terms of trade and financial development. As per the World Bank, about $27 \%$ of the world GDP was comprised of trade in 1970, which has increased to about $60 \%$ in 2019 (World Bank, 2019). Such a trend in the world economy has urged researchers to delve into analyzing relationships between technological factors and the growth of the countries. Until the 1950s, the exogenous growth theories didn't focus much on total factor productivity. The neoclassical theory assumed that the technology factors were exogeneous and unexplained within the growth model. However, along with globalization and with the development of endogenous growth theories, more focus has been laid on technological factors such as trade and Foreign Direct Investments (FDIs) especially in the case of developing countries. Mounir (2014) stated that the technological progress also explains the growth in any economy via spillover effects of the "tangible capital, human capital and research and development expenditures"(p. 272). Thus, technological factors can be of utmost importance especially for developing countries for increasing economic growth.

Trade openness and financial development are important factors for the growth of developing countries like Nepal which are labor intensive with a high level of unemployment. According to Montalbano (2011), "an open trade regime encourages integration of the economy into the global system and imports of modern technology, which results in productivity improvements"(p. 1489). Trade allows a developing country to receive technology transfers as well as import goods and services that are cheaper in other countries. This is termed as the spillover effect which Lucas (1988) explained in his endogenous growth model. Likewise, developing countries can export domestically produced goods and services, which helps to improve the balance of payment position by increasing foreign reserves. However, mixed literature can be found regarding the effect of trade openness on economic growth that show both positive and negative effects. On the other hand, trade openness can also make developing countries more dependent on imports regardless of technology transfers. Thus, trade openness will not necessarily drive the manufacturing sector of the developing economies and cause value addition.

In Nepal, the economic liberalization policy was enacted in 1984 B.S., which opened doors for financial institutions, traders as well as investors. Economic liberalization was followed by trade liberalization and financial liberalization which deregulated the role of the government and allowed the market to regulate itself. This accelerated the establishment of different types of financial institutions which in turn facilitated domestic investments in the country. Financial institutions play a vital role in the expansion of the manufacturing and trading sectors of the country by providing loans to those sectors. The gradual effect of liberalization in Nepal can also be seen from 1990 which accelerated international trade. Decrease in import tariffs, liberal trade policies and foreign direct investment policies were formulated, which caused a structural transformation of the country (Shrestha, 2017). Nepal became a member of the World Trade Organization in 2004 A.D which reduced administrative barriers and tariffs. This allowed for the further growth of finance, health, education, and many more sectors of the economy, either directly or indirectly.

Other factors such as domestic and foreign investments also influence the economic growth of the country. Gross Fixed Capital Formation which is one of the primary drivers of economic growth of any country alone constitutes 33.68\% of the GDP of Nepal (World Bank, 2019). On the other hand, the foreign direct investment in Nepal is $0.61 \%$ of GDP as of 2019 (UNCTAD, 2019). Nepal has one of the world's cheapest labor forces which is another driver for economic growth. Along with that, easy access to India and China and abundant natural resources can make FDI attractive in Nepal. However, Nepal is still behind on basic infrastructure such as roads and electricity which can discourage foreign 
investors. Despite the low FDI inflows in Nepal, it can contribute to the economic growth of the country directly or indirectly. Bista (2017) states that the FDI inflow will not only bring foreign investment but also technology and knowledge, increase competition in the market, increase the volume of export and develop the labor market. However, previous studies show that FDI inflows in Nepal don't adequately explain the economic growth of the country. There is a huge gap between approved FDIs and actual FDIs in Nepal. Also, Nepal hasn't been able to attract a huge amount of FDIs. The FDI inflows in Nepal has always been less than 1\% of GDP (UNCTAD, 2019). The reasons are time lag between the approved and actual investments, restrictions on rules and regulations, tariffs and political instability in the country. However, FDI stock inflows in Nepal increased significantly from the year 2008 A.D. when the political situation of the country stabilized.

This research paper examines the relationship between economic growth and capital, population, FDI, financial development and trade openness in Nepal using an endogenous growth model. The aim of this study is to point out significant factors that explain the economic growth of Nepal and to give necessary recommendations based on the findings for the policy implications. Moreover, this paper assesses whether technological factors such as FDI, financial development and trade openness explain the growth of Nepal. However, the paper has found a few limitations. Firstly, the study is strictly based on endogenous growth theory and aggregate production function and the variables are chosen based on this model. Therefore, other variables that might influence the economic growth of the country have been ignored. Secondly, proxy variables such as Gross Fixed Capital Formation for capital inputs, the population for labor inputs and broad money supply to GDP ratio for financial development are used, due to which the results cannot be generalized for each and every aspect of capital input, labor inputs and financial development.

The research paper is arranged into five sections. Section I consists of an introductory part which gives a brief preview of the study. Section II consists of a literature review which is further divided into two parts. The first part of it explains the production function theory behind the research which is the base model. The second part consists of the review of empirical studies that have been conducted in the past in the same or similar area of research. Section III contains the methodology of the study which includes data specification, mathematical model and empirical model. Section IV includes the data analysis and results of the study. Lastly, Section V presents the conclusion of the research.

\section{Review of Literature}

This chapter is divided into two parts: a) Review of Macroeconomic Theories and b) Review of empirical studies. The review of Macroeconomic Theories deals with the existing growth models that have been postulated till now. The review of empirical studies deals with prior research studies conducted both nationally and internationally on the relationships between economic growth, factor productivity and various factors of production.

\section{Review of Macroeconomic Theories}

There are different growth models that have attempted to explain the factors of growth over the past years. The prominent ones include Harrod (1939) and Domar (1946) growth models, Solow (1956) and Swan (1956) neoclassical growth models and Romer (1986) endogenous growth model, which have been described below.

\section{Harrod-Domar Growth Models}

Harrod (1939) and Domar (1946) growth models are based on Keynesian macroeconomic theory which stresses on the aggregate demand side of the economy to explain the growth. These models explain the growth in the national output in terms of savings and capital investments. Harrod (1939) assumed that saving is proportional to the national income and investment is proportional to the growth of national 
income which is termed as the accelerator. He further assumed that savings are equal to investments. Using these assumptions, Harrod showed that output grows at a $\frac{\mathrm{S}}{\mathrm{V}}$ rate which is the warranted growth rate, where $s=$ marginal propensity to save and $v=$ accelerator. Domar (1946) explained the growth in a slightly different form but arrived at the same conclusion as that of Harrod Model. He explained that investment has two sides namely income-generating effect and capacity generating effect. Domar showed that investment should grow at an exponential growth rate i.e, $\sigma . \alpha$, where $\sigma$ is the output capital ratio and $\alpha$ is the marginal propensity to save in order to maintain full employment. This equilibrium rate of growth is equal to the warranted growth rate $\left(G_{w}\right)$ as that of Harrod.

\section{Solow-Swan Neo-Classical Growth Models}

One of the assumptions under the Harrod-Domar model was the fixed proportion production function, where capital and labor aren't substitutable. Solow (1956) argued that the Harrod-Domar model was unstable due to this very assumption and the razor edge unstable equilibrium problem would disappear if this assumption was abandoned. Hence, Solow (1956) assumed that capital and labor are substitutable. He assumed that labor grows at a constant and exponential growth rate i.e, $n$. Other than this, the Solow model follows the same assumptions as that of Harrod and Domar models. Using saving and investment relations and the above assumptions, Solow derived a fundamental equation consisting of two components, namely capital widening and capital deepening. Capital widening is defined as the amount of capital accumulation that is required to keep the total capital constant as labor grows. Whereas, capital deepening is the capital accumulation that is required to increase the capital per worker. Unlike Harrod (1939) and Domar (1946) growth models, steady-state equilibrium is achieved in the Solow-Swan model where the capital, labor, investment and output grow at a constant and identical rate of $n$.

\section{Endogenous Growth Models}

The growth theorist, Solow (1956), in the past, assumed that the total factor productivity or technological factors were exogeneous and they couldn't be explained within the growth model. This unexplained part was termed as Solow residual. The endogenous growth theory is an improvement over the neo-classical theory which simply assumed that the marginal productivities of capital and labor were diminishing in nature. One of the major downsides of the Solow (1956) model was that it was unable to explain how technological progress would take place in any economy. It was simply assumed to be exogeneous in the model. However, technology has been considered a significant factor in the recent studies that endogenously explains the growth. The works of Romer (1986) and Lucas (1988) have emphasized human capital through "learning-by-doing" or schooling as technological factors that endogenously explains the growth of an economy.

\section{Review of International Empirical Studies}

With the advancement in endogeneous growth model theories, different forms of endogeneous growth model have been analyzed by researchers based on the countries and technological factors. Dritsaki, Dritsaki, \& Adamopoulos (2004) laid focus on the endogeneous growth model and examined the causal relationship between trade, FDI and economic growth in Greece using the Vector Autoregressive Model (VAR). They argued that export increases the productivity of an economy and further allows innovations. The liberalization not only induces trade but also causes FDI in the economy. The study concluded that FDI and GDP growth rate significantly and positively induce export of the country in the long run. Mounir (2014) used the same endogeneous growth model but used different econometric approach i.e, Autoregressive-Distributed Lag bound testing approach to examine the long-run relationship between economic growth, trade and FDI in Tunisia. The result found that cointegration existed only when FDI was the dependent variable. He found that trade openness and economic growth 
were significant determinants of FDI in the long run. The paper suggested that FDI was found to be prominent to bring a positive impact on the economic growth of the country.

In the case of developing countries, most of the literature state that productivity factors donot significantly explain the growth due to less amount of total factor productivity in such countries. Zebregs (1998) used a linear form of Cobb-Douglas production function to explain the effect of FDI in different countries under neo-classical growth theory and found out that low-income countries attracted lesser FDIs than other income group countries. Gurusamy \& Anbu (2010) came to a similar conclusion by examining the causal relationships between FDI inflows, trade and economic growth in India over the period 1970 to 2007. Although the study established cointegrating relationships among the variables, there were no causal relationships among the three variables in any direction. The study concluded that economic growth didn't have any effect on FDI and exports in India. However, trade liberalization and globalization have induced the growth of technological factors all over the world. There are some developing countries that have been able to channelize technology to produce positive growth. Ahmad, Hayat, Luqman, \& Ullah (2012) conducted a study in Pakistan to establish a link between FDI and economic growth of the country by using data from 1971 to 2007. Labor force and FDI were found to be positively significant, whereas domestic capital investment was found to be negatively significant in the long run. The study provides strong policy recommendations on inviting foreign investors and developing human capital inorder to influence economic progress in the country. Similarly, Magnus, Frimpong, Abayie, \& Fosu (2006) conducted a study in Ghana and derived an aggregate production function and found that capital and trade were positive and highly significant. Thus, it is found that developing countries haven't been able to steer all the technological factors into boosting the real output of the economy.

In developed economies, technology factors are found to be highly significant in inducing a positive growth. Slovakia, a European country, is considered to be a fast growing developed country. It has been able to push exports and make use of technological factors to maintain steady growth in the economy. Szkorupová (2014) analyzed the effects of FDI and export on the economic growth of Slovakia using the data from 2001 to 2010. The result showed that both FDI and exports were significant in inducing the economic growth of the country. Similarly, Acaravci (2010) showed that inward FDI and trade are highly significant in Turkey in inducing economic growth in the long run. However, it was also argued that import-based growth would lead to a worsening of the balance of payment position. Thus, exportbased growth should be prioritized in the country.

\section{Review of National Empirical Studies}

In the case of Nepal, very limited studies are available in terms of analyzing growth using endogeneous growth model. Moreover, studies on FDI in Nepal are very limited. Majagaiya, Pokhrel, \& Yan (2011) studied the relationship between FDI inflows and economic growth of Nepal using the data of the period 1983 to 2007 where GDP was the dependent variable. The log-linear Cochrane-Orcutt regression model showed that the FDI coefficient was not significant. Hence, the study was not able to explain the relationship between FDI and economic growth of Nepal adequately without the presence of autocorrelation. Bista \& Bista (2018) examined the relationship between economic growth, trade openness and financial development. Growth proxies like real GDP growth and real GDP per capita growth were taken as dependent variables. Credit to the private sector was taken as a proxy for financial development in the study. The long-run coefficients indicated a positive and significant relationship between GDP growth credit to the private sector. However, trade was negative in the long run. Elliot \& Kulkarni (2006) also analyzed the relationship between FDI and the economic growth of Nepal and found that no strong relationship exists between these two. The study pointed out several reasons for not being able to attract FDI in Nepal such as poor infrastructure in the country, low literacy rates, restrictions, taxes and political instability. The study suggested various policies in order to 
bring in more FDI in the country such as law regulations, tax amendments, favorable labor laws and development of infrastructure in the country. The research also suggested that Nepal can attract FDI in areas such as agriculture, tourism, herbal industry and hydropower. Therefore, the study emphasized the government's role to regulate and allow privatization of these sectors.

The literature identified that very little amount of studies have been conducted using endogeneous growth model in Nepal. Moreover, it is found that studies in Nepal haven't utilized FDI stock inflows data since the direct and indirect effects of FDI can be captured better with stock data rather than flow data (Mehic, Silajdzic, \& Hodovic, 2014). The only studies that have taken place have utilized flow data of FDI. Thus, this paper is aimed at analyzing the determinants of output in Nepal and filling in these missing gaps using an aggregate production function based on endogenous growth model.

\section{Research Method}

\section{Model}

Cobb-Douglas production function is one of the oldest production functions developed by C.W Cobb and P.H. Douglas in order to determine the relationships between the factors of production and output. The production function allows us to calculate the contributions or shares of factors of production such as capital and labor in the output. The original version of the C-D production function as developed by Cobb \& Douglas (1928) is presented as $U=C \cdot a^{\lambda} K^{i}$ where $U=$ Total output, $C=$ constant, $a=$ labor input, $\lambda=$ elasticity of output with respect to labor, $K=$ capital and $i=$ elasticity of output with respect to the capital. Later on, Paul Douglas transformed the production function into $P=a \cdot L^{\alpha}$. $C^{\beta}$ where $P$ = Output, $a=$ constant, $L=$ labour, $\alpha=$ elasticity of output with respect to labor, $C=$ capital and $\beta=$ elasticity of output with respect to the capital. Such a production function is homogeneous to the degree $(\alpha+\beta)$ which indicates the increasing, decreasing or constant returns to scale.

The aggregate production function is the macroeconomic derivation of the Cobb-Douglas production function where aggregate output is the function of total factor productivity, capital inputs and labor inputs. Alezzee (2014) states that "the aggregate production function is the maximum output that can be produced given the quantities of the factors of production"(p. 129). Aggregate production function defines the total output of the economy which is the function of capital, labor and total factor productivity of the economy. The general form of the aggregate production function is defined as $Y_{t}=$ $A_{t} K_{t}^{\alpha} L_{t}^{\beta}$ where $\mathrm{Y}_{t}$ denotes aggregate production of the economy at time $t, A_{t}$ denotes the total factor productivity and $K_{t}$ and $L_{t}$ denote capital inputs and labor inputs respectively. The $\alpha$ and $\beta$ represent output elasticities of capital and labor respectively.

\section{Data and Variables}

The research incorporates secondary data into the study. Annual time series data of real GDP (in million rupees), gross fixed capital formation (in million rupees), population (in millions), broad money supply to GDP ratio and trade to GDP ratio has been obtained from the database of the Nepal Rastra Bank. Whereas, FDI stock inflows to GDP ratio data was obtained from UNCTAD (2019) covering the period from 1980 to 2018 A.D. Since the data before 1980 wasn't available and data on FDI net inflows is missing from 1992 to 1995, the study employs FDI stock inflows. FDI stock is approximated from the past values of the accumulated FDI (UNCTAD, 2019). FDI stock inflows have been incorporated instead of FDI net inflows due to various reasons. Firstly, FDI stock better captures the direct and indirect effects of FDI as the effect is not instantaneous (Mehic, Silajdzic, \& Hodovic, 2014). Secondly, FDI stock can be calculated and used in case of missing observations (Pegkas, 2015). The descriptions of the variables are presented in the following table: 
Table 1: Description of Variables

\begin{tabular}{clc}
\hline S.No. & \multicolumn{1}{c}{ Variables } & Notation \\
\hline 1. & Real GDP & GDP \\
2. & Gross Fixed Capital Formation & GFCF \\
3. & Population & POP \\
4. & FDI stock inflow to GDP ratio & FDI \\
5. & Broad money supply to GDP ratio & FIN \\
6. & Trade to GDP ratio & TRADE \\
\hline
\end{tabular}

The Gross Domestic Product is taken at a constant price of FY 2000/2001 A.D. in order to measure economic growth. FDI is the ratio of stock inflow of foreign direct investment to GDP. TRADE measures the trade openness which is simply the sum of imports and exports of the country divided by its GDP at time t. In order to measure the impact of financial development on economic growth, a proxy variable FIN is used which is the ratio of broad money supply to GDP (Apergis, Lyroudi, \& Vamvakidis, 2008). GFCF is a proxy variable for capital input which represents domestic investment in the country. POP is a proxy variable for labor inputs of the country.

\section{Mathematical Model}

In order to examine the relationship between trade openness, FDI and financial development with economic growth, aggregate production function used by Herzer, Lehmann, \& Siliverstovs (2006) based on neo-classical production function is formulated as follows:

$$
\begin{gathered}
Y_{t}=A_{t} \cdot K_{t}^{\alpha} \cdot L_{t}^{\beta} \\
o r, G D P_{t}=A_{t} \cdot G F C F_{t}^{\alpha} \cdot P O P_{t}^{\beta}
\end{gathered}
$$

Where $G D P_{t}$ represents real $G D P, A_{t}$ represents total factor productivity, $G F C F_{t}$ represents the proxy variable for capital inputs and $\mathrm{POP}_{t}$ represents the total population at the time $t$. The $\alpha$ and $\beta$ denote the elasticity of capital and population respectively with respect to the output. The literature reviews showed that economic growth is dependent on capital inputs, labor inputs and total factor productivity which includes trade, foreign direct investment and other variables. Magnus, Frimpong, Abayie, \& Fosu (2006) showed that total factor productivity is the function of trade and foreign direct investment. Apergis et al (2008) also incorporated financial development into their model in order to establish its relationship with the economic growth of 27 transition economies by employing a panel cointegration method. Thus, total factor productivity is taken as a function of FDI inflows (FDI), trade (TRADE) and financial development (FIN). In this study, FDI stock inflows, financial development and trade openness are incorporated as the function of total factor productivity.

$$
A_{t}=f\left(F D I_{t}^{\psi} \cdot F_{t}^{\phi} \cdot T R A D E_{t}^{\theta}\right)
$$

From equation (i) and (ii), the following equation is obtained :

$$
G D P_{t}=f\left(G F C F_{t}^{\alpha} . P O P_{t}^{\beta} . F D I_{t}^{\psi}, F I N_{t}^{\phi}, T R A D E_{t}^{\theta}\right)
$$

Where $\alpha, \beta, \psi, \phi$ and $\theta$ are the coefficients of the variables.

\section{Econometric Model}

The aggregate production function derived in equation (iii) is estimated by taking a natural logarithm on both sides at the time t. The log transformation is shown in the following equation:

$$
\ln G D P_{t}=c+\alpha \ln G F C F_{t}+\beta \ln P O P_{t}+\psi F D I_{t}+\phi F I N_{t}+\theta T R A D E_{t}+\epsilon_{t} \ldots
$$

Where $\alpha$ and $\beta$ represent output elasticity coefficients with respect to gross fixed capital formation and population. Similarly, $\psi, \phi$ and $\theta$ when multiplied by $100 \%$ represent percentage change in the per 
capita GDP due to a unit (1 percentage) change in FDI, FIN and TRADE respectively. Thus, the other coefficients can also be interpreted in the elasticity form.

The above equation gives us the relationship between economic growth and all the explanatory variables and the long-run coefficients can be estimated given that there exists cointegration between them. In order to establish a long-run cointegrating relationship between the variables, an ARDL bound testing approach by Shin, J., \& Pesaran (2001) is used. The concept of cointegration was first formulated by Granger (1981) and Engle \& Granger (1987) which can only be used when one cointegrating vector exists (Nkoro \& Uko, 2016). This method can only be used if the time series is stationary after the first difference and cointegration are established once their linear combination is stationary at level. The bound testing approach developed by Shin, J., \& Pesaran (2001) has several advantages over Engle \& Granger (1987) and Johansen (1988) methods of cointegration. Firstly, bound testing can be used irrespective of the order of integration of the variables. However, the variables should be either $\mathrm{I}(0)$ or I(1). The procedure will crash in case of the presence of I(2) series (Magnus, Frimpong, Abayie, \& Fosu, 2006). Secondly, more than one cointegrating relationship can be estimated using ARDL. Finally, the ARDL method is considered to be robust and suitable in a small sample size (Nkoro \& Uko, 2016). The ARDL model ( $\left.\mathrm{p}, \mathrm{q}_{1}, \mathrm{q}_{2}, \mathrm{q}_{3}, \mathrm{q}_{4}, \mathrm{q}_{5}\right)$ used in this study is specified as follows:

$$
\begin{gathered}
\Delta \ln G D P_{t}=a_{0}+\sum_{i=1}^{p} \lambda_{1 i} \Delta \ln G D P_{t-i}+\sum^{q 1}{ }_{i=0} \alpha_{2 i} \Delta \ln G F C F_{t-i}+\sum_{i=0}^{q 2} \beta_{3 i} \Delta \ln P O P_{t-i}+\sum_{i=0}^{q 3} \psi_{4 i} \Delta F D I_{t-i}+ \\
\sum^{q 4}{ }_{i=0} \phi_{5 i} \Delta F I N_{t-i}+\sum^{q 5}{ }_{i=0} \theta_{6 i} \Delta T R A D E_{t-i}+\gamma_{1} \ln G D P_{t-1}+\gamma_{2} \ln G F C F_{t-1}+\gamma_{3} \ln P O P_{t-1}+\gamma_{4} F D I_{t-1}+ \\
\gamma_{5} F_{t-1}+\gamma_{6} \operatorname{TRADE} E_{t-1}+U_{t} \ldots \ldots(5)
\end{gathered}
$$

The order of lags in the above model is selected under the Schwarz Bayesian Criterion (SBC).

\section{Hypothesis}

In order to test whether long-run relationship exists between economic growth and other variables, the hypothesis is set as follows:

$$
\begin{gathered}
H_{0}: \gamma_{1}=\gamma_{2}=\gamma_{3}=\gamma_{4}=\gamma_{5}=\gamma_{6}=0 \\
H_{1}: \gamma_{1} \neq \gamma_{2} \neq \gamma_{3} \neq \gamma_{4} \neq \gamma_{5} \neq \gamma_{6} \neq 0
\end{gathered}
$$

The F-statistic is calculated and then compared to upper bound and lower bound critical values. The two sets of critical values at different significance levels are given by Shin, J., \& Pesaran (2001). If the calculated F-statistic is lower than the lower bound critical value, the null hypothesis cannot be rejected. Whereas, the null hypothesis is rejected in the case where F-statistic is higher than the upper bound critical values. The result is inconclusive if the value lies between the upper bound and lower bound. Once the cointegration is established, the conditional ARDL $\left(p, q_{1}, q_{2}, q_{3}, q_{4}, q_{5}\right)$ is used to estimate long-run coefficients using the following equation:

$$
\begin{aligned}
& \ln G D P_{t}=a_{1}+\sum_{i=1}^{p} \lambda_{1 i} \ln G D P_{t-i}+\sum_{i=0}^{q 1} \alpha_{2 i} \ln G F C F_{t-i}+\sum_{i=0}^{q 2} \beta_{3 i} \ln P O P_{t-i}+\sum_{i=0}^{q 3} \psi_{4 i} F D I_{t-i}+ \\
& \sum^{q 4}{ }_{i=0} \phi_{5 i} \text { FIN }_{t-i}+\sum^{q 5}{ }_{i=0} \theta_{6 i} \operatorname{TRADE}_{t-i}+\epsilon_{t} \ldots \ldots \ldots \ldots \ldots \ldots \ldots(6)
\end{aligned}
$$

Once the cointegration is established, an error correction model (ECM) is introduced to estimate shortrun dynamic parameters following the paper of Odhiambo (2007) where the relationship between economic growth and energy consumption is established. The error correction term is estimated from the long-run model and its lagged value is plugged into the error correction model. The ECM can be specified as follows:

$$
\begin{aligned}
\Delta \ln G D P_{t}=a_{0}+\sum^{p} \sum_{i=1} \lambda_{1 i} \Delta \ln G D P_{t-i}+\sum_{i=0}^{q 1} \alpha_{2 i} \Delta \ln G F C F_{t-i}+\sum_{i=0}^{q 2} \beta_{3 i} \Delta \ln P O P_{t-i}+\sum_{i=0}^{q 3} \psi_{4 i} \Delta F D I_{t-i}+ \\
\sum_{i=0}^{q 4} \phi_{5 i} \Delta F I N_{t-i}+\sum_{i=0}^{q 5}{ }_{6 i} \Delta T R A D E_{t-i}+\delta E C T_{t-1}+\epsilon_{t} \ldots \ldots \ldots . .(7)
\end{aligned}
$$

Where ECT is the error correction term and $\delta$ is the speed of adjustment to equilibrium after a shock. The negative sign indicates convergence to long-run equilibrium whereas the positive sign indicates divergence. 
For examining the stability of the model, CUSUM and CUSUMQ tests are used and the AR roots graph is examined. As for the diagnostics, Ramsey's RESET test is carried out to check functional misspecification of the model. A Jarque-Bera test is conducted to test the assumption of normality. Lagrange Multiplier (LM) test is carried out for serial correlation and KB test for heteroscedasticity. For ensuring the robustness of the model and pointing out the direction of causality, TY non-GrangerCausality test is incorporated in this study.

\section{Data Analysis and Result}

\section{Descriptive Statistics}

Table 2 shows descriptive statistics of dependent and independent variables used in the study. GDP represents the real Gross Domestic Product in million rupees, GFCF represents real Gross Fixed Capital Formation in million rupees and POP represents the total population of the country in millions. On the other hand, FDI is defined as Foreign Direct Investment stock inflows to GDP ratio, FIN is defined as broad money supply to GDP ratio and TRADE is defined as trade openness or trade to GDP ratio.

Table 2: Descriptive Analysis

\begin{tabular}{lcccccc}
\hline Statistics & GDP & GFCF & POP & FDI & FIN & TRADE \\
\hline Mean & 430739.2 & 170342.2122 & 21.8885 & 1.5485 & 48.6622 & 32.3765 \\
Median & 393902.9 & 65373.6185 & 22.1337 & 1.0791 & 44.6737 & 35.3198 \\
Maximum & 887816.7 & 1056894.2040 & 29.1460 & 7.1452 & 101.6270 & 43.5630 \\
Minimum & 155131.2 & 3680.1176 & 14.6338 & 0.0152 & 22.6341 & 19.8304 \\
Std. Dev. & 207913.3 & 244963.7269 & 4.4666 & 1.9156 & 22.6892 & 7.3436 \\
Skewness & 0.52015 & 2.0995 & -0.0365 & 1.8016 & 0.9017 & -0.4939 \\
Kurtosis & 2.1756 & 6.9306 & 1.7095 & 5.4465 & 2.8371 & 1.7759 \\
Jarque-Bera & 2.8631 & 53.7582 & 2.7149 & 30.8233 & 5.3279 & 4.0205 \\
Probability & 0.2389 & 0.0000 & 0.2573 & 0.0000 & 0.0697 & 0.1340 \\
Observations & 39 & 39 & 39 & 39 & 39 & 39 \\
\hline
\end{tabular}

\section{Trend Analysis}

The trends of the variables are examined in figure 1. The real sector variables such as GDP and GFCF are found to be increasing over the period without any sort of structural breaks. The FDI inflows in Nepal were found to be really slow until the year 2008. After the year 2008, FDI inflows in the country increased gradually which can be attributed to the end of civil war and the start of the peace process (NRB, 2018). The FDI stock in flows were at about 1\% of GDP in 2008 which increased to a whopping $7 \%$ in the year 2018 (UNCTAD, 2019). Similarly, the broad money supply is found to be increasing overtime. The trade sector in Nepal has accelerated ever since economic liberalization was introduced in the mid-1980s. The effect of liberalization, however, can be seen in the trade from the year 1990. The trade to GDP ratio was $22.71 \%$ in 1990 which gradually increased to $37.10 \%$ in 1995 (NRB, 2020). A major share of trade openness of Nepal consists of imports which is found to be growing exponentially over the past years. However, the share of exports is very less. Nepal also became a member of the South Asian Preferential Trade Agreement (SAPTA) in 1995 which decreased import barriers and promoted transit facilities among the SAARC countries (Pant, 2005). 


\section{Figure 1: Trend of Macroeconomic Variables}
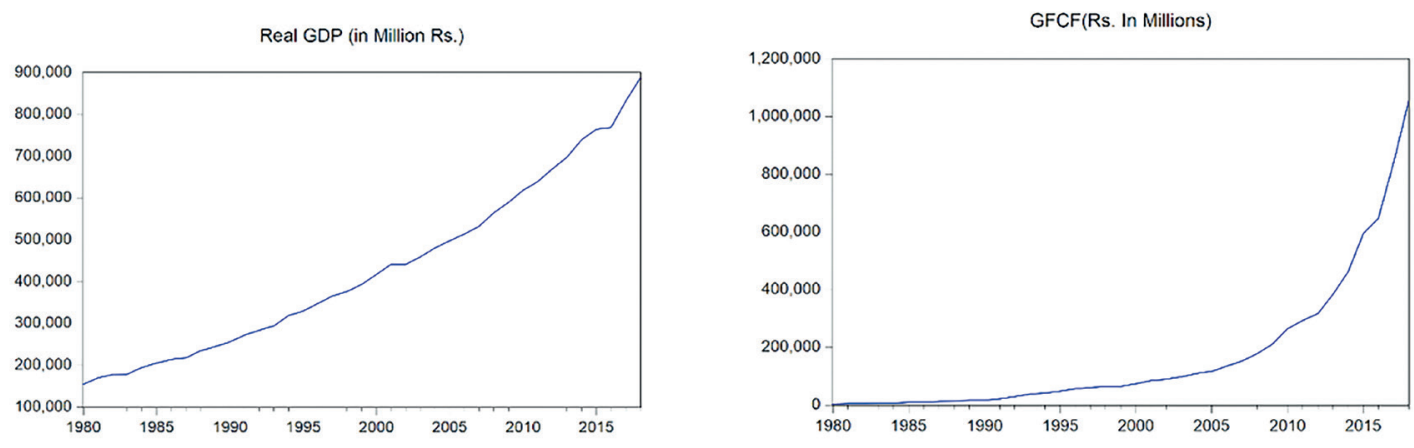

Population (in Millions)

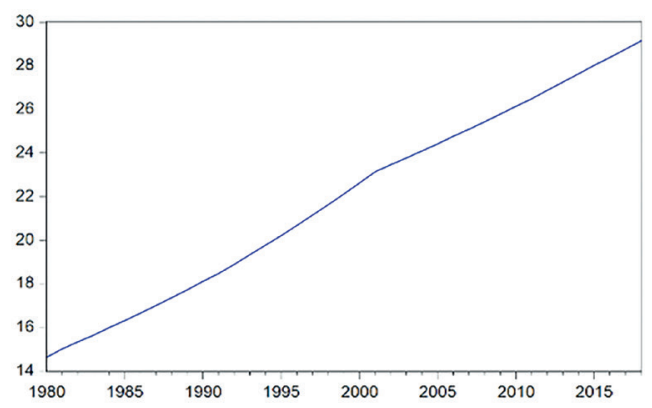

FDI Stock- GDP ratio (\%)

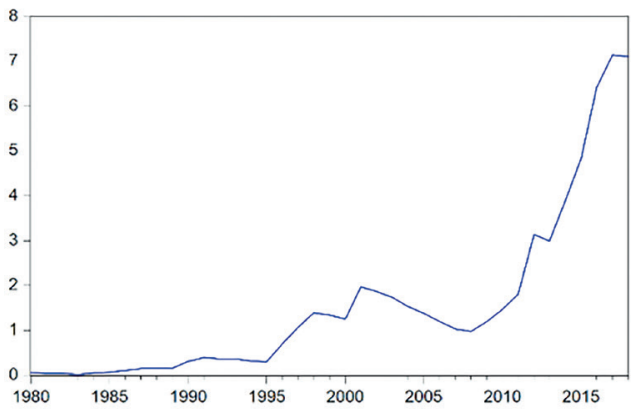

M2-GDP ratio (\%)
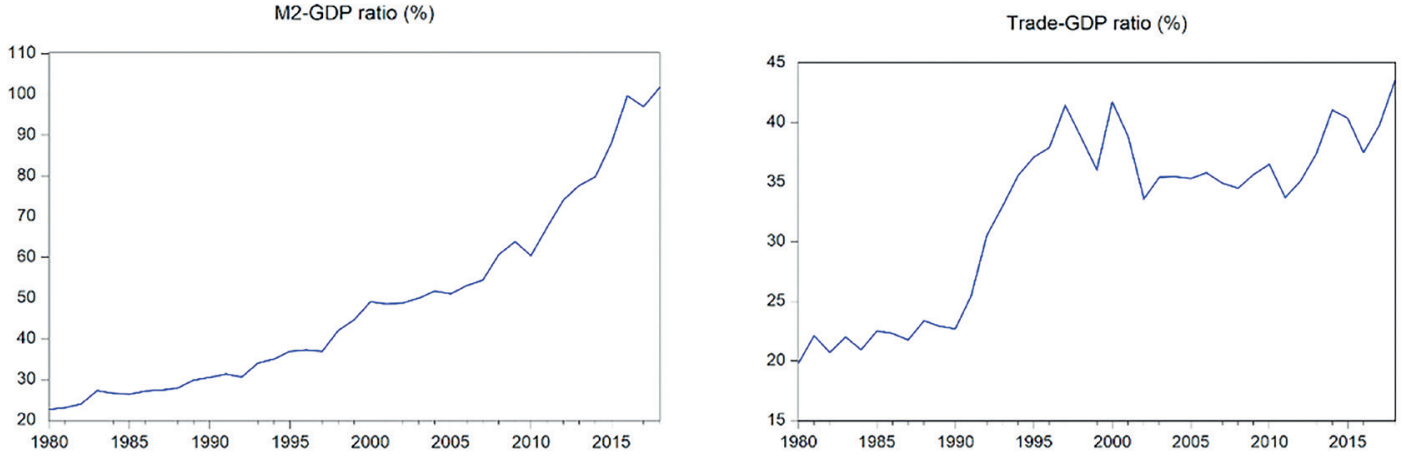

\section{Unit Root Tests}

Before running the causality test, the unit root test is carried out to check for the stationarity of the variables. Shin, J., \& Pesaran (2001) states that there is no need for carrying out the unit root tests to check for cointegration under the ARDL approach as bound tests for cointegration can be carried out in the presence of both $\mathrm{I}(0)$ and $\mathrm{I}(1)$ series. However, the ARDL bound test process would crash in the presence of I(2) variables (Nkoro \& Uko, 2016). The variables must be stationary in order to avoid spurious regression results. If the random walks are involved in time series analysis, the regression will produce a very high goodness of fit (high $\mathrm{R}^{2}$ value) and low Durbin-Watson statistic (Granger \& Newbold, Forecasting Economic Time Series, 1986). This leads to inaccurate estimation 
and forecast. The Bounds test can be carried out once the variables are stationary at either level or first difference. Augmented Dicky-Fuller, Phillips-Perron and KPSS tests are applied to check for unit root. The statistics are given as follows:

Table 3: Unit Root Tests

ADF Unit Root Tests

\begin{tabular}{|c|c|c|c|c|c|}
\hline \multicolumn{3}{|c|}{ Level } & \multicolumn{3}{|c|}{ First Difference } \\
\hline Variable & Constant & $\begin{array}{c}\text { Constant and } \\
\text { Trend }\end{array}$ & Variable & Constant & $\begin{array}{c}\text { Constant and } \\
\text { Trend }\end{array}$ \\
\hline $\operatorname{lnGDP}$ & -1.6497 & $-3.3056^{*}$ & $\Delta \operatorname{lnGDP}$ & $-7.7576^{* * *}$ & $-8.0247 * * *$ \\
\hline $\operatorname{lnGFCF}$ & -0.1528 & -1.5565 & $\triangle \operatorname{lnGFCF}$ & $-6.4984 * * *$ & $-6.3909 * * *$ \\
\hline $\ln \mathrm{POP}$ & -1.5579 & -0.2456 & $\Delta \ln \mathrm{POP}$ & -1.7132 & -2.2698 \\
\hline FDI & 2.8524 & 0.7014 & $\Delta$ FDI & $-3.8454 * * *$ & $-4.4361 * * *$ \\
\hline FIN & 4.1580 & -0.2427 & $\Delta \mathrm{FIN}$ & $-5.6168 * * *$ & $-6.0328 * * *$ \\
\hline TRADE & -1.1679 & -2.6042 & $\triangle \mathrm{TRADE}$ & $-2.8108 *$ & $-5.3760 * * *$ \\
\hline
\end{tabular}

Phillips-Perron Unit Root Test

\begin{tabular}{|c|c|c|c|c|c|}
\hline \multicolumn{3}{|c|}{ Level } & \multicolumn{3}{|c|}{ First Difference } \\
\hline Variable & Constant & $\begin{array}{c}\text { Constant and } \\
\text { Trend } \\
\end{array}$ & Variable & Constant & $\begin{array}{c}\text { Constant and } \\
\text { Trend } \\
\end{array}$ \\
\hline $\operatorname{lnGDP}$ & -1.7381 & $-3.2939 *$ & $\Delta \operatorname{lnGDP}$ & $-9.0376 * * *$ & $-9.3786 * * *$ \\
\hline $\operatorname{lnGFCF}$ & -0.1600 & -1.6847 & $\Delta \operatorname{lnGFCF}$ & $-6.5017 * * *$ & $-6.4081 * * *$ \\
\hline $\ln \mathrm{POP}$ & -4.4730 & 0.0027 & $\Delta \ln \mathrm{POP}$ & -2.4379 & -2.4379 \\
\hline FDI & -0.5595 & 0.7014 & $\Delta \mathrm{FDI}$ & $-3.7709 * * *$ & $-4.4361 * * *$ \\
\hline FIN & 7.4273 & 0.2027 & $\Delta \mathrm{FIN}$ & $-5.6348 * * *$ & $-7.0833 * * *$ \\
\hline TRADE & -1.0914 & -1.8443 & $\triangle \mathrm{TRADE}$ & $-5.8812 * * *$ & $-5.7530 * * *$ \\
\hline \multicolumn{6}{|c|}{ KPSS Unit Root Test } \\
\hline \multicolumn{3}{|c|}{ Level } & \multicolumn{3}{|c|}{ First Difference } \\
\hline Variable & Constant & $\begin{array}{c}\text { Constant and } \\
\text { Trend }\end{array}$ & Variable & Constant & $\begin{array}{c}\text { Constant and } \\
\text { Trend }\end{array}$ \\
\hline $\operatorname{lnGDP}$ & $0.7646 * * *$ & $0.1764 * *$ & $\Delta \operatorname{lnGDP}$ & 0.2576 & $0.1632 * *$ \\
\hline $\operatorname{lnGFCF}$ & $0.7637 * * *$ & 0.1099 & $\triangle \operatorname{lnGFCF}$ & 0.1755 & $0.1756^{* *}$ \\
\hline $\operatorname{lnPOP}$ & $0.7577 * * *$ & $0.1954 * *$ & $\Delta \ln \mathrm{POP}$ & $0.5978 * *$ & 0.1010 \\
\hline FDI & $0.6074 * *$ & $0.1505^{* *}$ & $\Delta \mathrm{FDI}$ & $0.3878 *$ & $0.1257^{*}$ \\
\hline FIN & $0.7237 * *$ & $0.2033 * *$ & $\Delta \mathrm{FIN}$ & $0.6316 * *$ & 0.1144 \\
\hline TRADE & $0.5897 * *$ & $0.1331 *$ & $\triangle \mathrm{TRADE}$ & 0.1096 & 0.0788 \\
\hline
\end{tabular}

Note: $* * *, * *$ and $*$ indicates significance level at $1 \%, 5 \%$ and $10 \%$ respectively.

Table 3 shows different unit root test results under different conditions for all the variables. The ADF and P-P tests show that all the variables except the population are stationary in the first difference at a $1 \%$ level of significance. However, the KPSS unit root test suggests the non-rejection of not having unit root in the first difference at a 5\% level of significance for the population. Perron (1989) argued that the standard unit root tests may lead to biased results due to false non-rejection of having unit roots in the presence of any structural break in the series. The plot in figure 1 also visually suggests that there 
might be some structural breaks present in the series. Therefore, the unit root test in the presence of a structural break is conducted in order to test the unit root hypothesis and break date in the series.

Table 4: Zivot-Andrews Structural Break Unit Root Test

Zivot-Andrews Unit Root Test

\begin{tabular}{cccc}
\hline Variables & t- statistic & Year of Break & Results \\
\hline lnGDP & $-3.5065^{* * *}$ & 2002 & Stationary \\
lnGFCF & -2.9605 & 2011 & Non- Stationary \\
lnPOP & $-6.2926^{* * *}$ & 2000 & Stationary \\
FDI & $-3.6329^{* * *}$ & 2007 & Stationary \\
FIN & -2.0504 & 2010 & Non- Stationary \\
TRADE & $-3.7126^{*}$ & 1992 & Stationary \\
\hline
\end{tabular}

Note: $* * *, * *$ and $*$ indicates significance level at $1 \%, 5 \%$ and $10 \%$ respectively.

Zivot and Andrews (1992) developed a unit root test that exogenously determines structural break date in the series. The results show that LNGDP, LNPOP, FDI and TRADE reject the null hypothesis of having unit roots at the level. The structural break in GDP series can be attributed to the Royal Massacre which took place in 2001. The growth slowed down abruptly with revenue growth remaining at only $4.5 \%$ as compared to $13.2 \%$ in 2001 (ADB, 2003). The structural break in GFCF is due to the rapid increase in private investments over the past years as compared to government investments. The population growth rate is found to be increasing at a decreasing rate after 2000 A.D due to the decline in births and an increase in outmigration (NPC, 2017). The FDI inflows in Nepal accelerated after 2007 when the peace process was initiated and a comprehensive peace agreement was signed in Nepal after the Maoists joined the government. This also led to the financial development of the economy. Moreover, the increase in the money supply was caused also due to the massive amount of remittance inflows in the country (World Bank, 2014). The structural break in trade openness can be attributed to the trade liberalization reform programs after the 1990s when the multi-party democracy was restored (Bhatt \& Sharma, 2006).

\section{Bounds Test for Co-integration}

In order to establish a long-run relationship between economic growth and other control variables, the ARDL model is run for the bounds test. Vector Autoregressive (VAR) model is used to select the lag length. The VAR lag length criteria have been presented in table 5. Schwarz information criterion is used to select lag length in the model. The first level of the bounds test is carried out on the assumption that the variables are integrated of order zero. Secondly, the test is carried out on the assumption that the variables are integrated of order 1 . The calculated F-statistic is compared with the critical values at various levels of significance as given by Shin, J., \& Pesaran (2001). The results are presented in the following tables.

Table 5: VAR Lag Length Criteria

\begin{tabular}{ccccccc}
\hline Lag & LogL & LR & FPE & AIC & SC & HQ \\
\hline 0 & -22.5672 & NA & $2.06 \mathrm{E}-07$ & 1.632413 & 1.899044 & 1.724454 \\
1 & 279.5893 & 483.4505 & $5.29 \mathrm{E}-14$ & -13.5765 & $-11.71012^{*}$ & -12.9323 \\
2 & 329.6378 & 62.91807 & $2.87 \mathrm{E}-14$ & -14.3793 & -10.9131 & -13.1828 \\
3 & 387.1472 & $52.58002^{*}$ & $1.47 \mathrm{E}-14$ & -15.6084 & -10.5424 & -13.8596 \\
4 & 468.2984 & 46.37212 & $4.49 \mathrm{e}-15^{*}$ & $-18.18848^{*}$ & -11.5227 & $-15.88746^{*}$ \\
\hline
\end{tabular}


Note:*indicates lag order selected by the criterion, LR: sequential modified LR test statistic ( $5 \%$ level), FPE: Final prediction error, AIC: Akaike information criterion, SC: Schwarz information criterion, HQ: Hannan-Quinn information criterion.

Table 5 shows different lag length criteria. Schwarz Information Criterion is chosen because SIC criteria are often found to perform slightly better than other criteria in small sample sizes and it is also robust (Pesaran \& Shin, 1997). The maximum lag of 1 is selected based on it, as shown in the table.

Table 6: Results from Bounds Test

\begin{tabular}{lccc}
\hline \multicolumn{1}{c}{ Variables } & SIC lags & Value & Decision \\
\hline F(lnGDP $\backslash \operatorname{lnGFCF,lnPOP,FDI,FIN,TRADE)~}$ & $(1,0,0,0,1,0)$ & 39.246 & Cointegration \\
F(lnGFCF $\backslash \operatorname{lnGDP,lnPOP,FDI,FIN,TRADE)~}$ & $(1,1,0,0,0,1)$ & 2.7228 & No \\
F(lnPOP $\backslash \operatorname{lnGDP,lnGFCF,FDI,FIN,TRADE)~}$ & $(1,0,0,1,1,0)$ & 25.49 & Cointegration \\
F(FDI $\backslash$ lnGDP,lnGFCF, lnPOP,FIN,TRADE) & $(1,0,0,1,0,0)$ & 6.2108 & Cointegration \\
F(FIN $\backslash \operatorname{lnGDP,lnGFCF,~lnPOP,FDI~,TRADE)~}$ & $(1,1,0,0,0,0)$ & 1.9729 & No \\
F(TRADE $\backslash \operatorname{lnGDP,lnGFCF,lnPOP,FDI,FIN)~}$ & $(1,0,0,1,1,0)$ & 4.8153 & Cointegration \\
\hline Critical Values & $\mathbf{I}(\mathbf{0})$ & $\mathbf{I}(\mathbf{1})$ & \\
\hline $10 \%$ & 2.26 & 3.35 & \\
$5 \%$ & 2.62 & 3.79 & \\
$1 \%$ & 3.41 & 4.68 & \\
\hline
\end{tabular}

The above table shows calculated F-statistics and critical values given by (Shin, J., \& Pesaran, 2001). The bounds test suggests that four long-run cointegrating relationship exists when $\operatorname{lnGDP}, \ln P O P$, FDI and TRADE are dependent variables. Hence, the null hypothesis of no cointegration is rejected. However, there is no cointegration when $\mathrm{lnGFCF}$ and FIN are dependent variables. The unit root and bound tests hence confirm the long-run cointegration relationship. Since the determinants of growth under endogenous growth model framework is to be analyzed, the cointegrating equation, when lnGDP is a dependent variable, is computed. Therefore, the long-run and short-run dynamics of the ARDL model can be estimated.

\section{ARDL Results}

The optimal number of lags is selected based on Schwarz Bayesian Criterion. The VAR lag length criteria is used to select the optimal number of lags. The maximum number of lags chosen by the SC criteria was 1 , hence the number of optimal lags for our model is ARDL $(1,0,0,0,1,0)$ for each of the variables. The estimated long-run coefficients from the ARDL $(1,0,0,0,1,0)$ model is presented in the following table. The optimal lag lengths have been selected using SIC criteria.

Table 7: Long-run Coefficients

\begin{tabular}{ccccc}
\hline Variables & Coefficient & Std. Error & t-Statistic & Prob. \\
\hline $\ln$ GFCF & 0.099243 & 0.021305 & 4.658268 & $0.0001^{* * *}$ \\
$\ln$ POP & 1.331431 & 0.131405 & 10.13228 & $0.0000^{* * *}$ \\
FDI & -0.00819 & 0.003032 & -2.70048 & $0.0113^{* *}$ \\
FIN & 0.002066 & 0.000526 & 3.926 & $0.0005^{* * *}$ \\
TRADE & 0.000075 & 0.000502 & 0.149876 & 0.8819 \\
C & 3.250739 & 0.101656 & 31.9779 & 0.0000 \\
\hline
\end{tabular}

Note: $* * * * *$ and $*$ indicates significance level at $1 \%, 5 \%$ and $10 \%$ respectively. 
The long run equation of the ARDL $(1,0,0,0,1,0)$ model can be presented as follows:

$$
\ln G D P_{t}=3.2507+0.0992 \ln G F C F_{t}+1.331 \ln P O P_{t}-0.0082 F D I_{t}+0.0020 F I N_{t}+0.000075 T_{R A D E}
$$

The estimates in table 7 show that Gross Fixed Capital Formation and population are highly significant at $1 \%$. The long-run elasticity of GFCF is 0.10 which translates to a $0.1 \%$ increase in economic growth due to a $1 \%$ increase in the capital formation of the country. The long-run elasticity of POP is 1.3 which translates to a $1.3 \%$ increase in the economic growth of the country due to a $1 \%$ increase in the population of the country. The results closely match the study of Nepal \& Paija (2019) in which they examined the relationship between output, electricity consumption, capital, and labor. Capital and labor were found to be positive and significant in relation to the real GDP of Nepal in their study. Similarly, FDI and FIN are also highly significant. A percentage increase in FDI stock inflows of the country leads to the negative growth of GDP by $0.8 \%$. Therefore, there is a negative relationship between the economic growth and accumulated FDI stock inflows of the country. Similarly, a $1 \%$ increase in money supply to GDP ratio of the country induces the growth of real GDP by $0.2 \%$. This result reveals that financial development is also significant for pushing the economic growth of Nepal. Paudel \& Khatri (2018) found that real GDP granger causes the broad money supply to GDP ratio in Nepal in their study which supports this finding. However, trade is found to be insignificant in this model. The trade openness hasn't been able to cause value addition in the GDP of Nepal despite the high trade-GDP ratio. Bista \& Bista (2018) also showed that trade openness doesn't cause positive growth in Nepal. A major share of trade of Nepal consists of imports which are not found to be further used for production or value addition but consumption. The export was $2.7 \%$ of GDP and the import was $40.9 \%$ of the GDP in 2018 (NRB, 2020).

Table 8: Error Correction Model Estimation

\begin{tabular}{ccccc}
\hline Variable & Coefficient & Std. Error & t-Statistic & Prob. \\
\hline D(lnGFCF) & 0.0445 & 0.0287 & 1.5499 & 0.131 \\
D(lnPOP) & 1.4544 & 0.2718 & 5.3515 & $0.000^{* * *}$ \\
D(FDI) & -0.0041 & 0.0029 & -1.4142 & 0.167 \\
D(FIN) & 0.0002 & 0.0004 & 0.4421 & 0.661 \\
D(TRADE) & 0.0008 & 0.0005 & 1.7783 & $0.085^{*}$ \\
ECT $(-1)$ & -0.8223 & 0.1355 & -6.0684 & $0.000^{* * *}$ \\
$\mathrm{R}^{2}=0.5026$ & $\overline{\mathrm{R}}^{2}=0.3867$ & F-Stat $=4.3322[0.002]$ & DW Statistic $=1.9305$ & \\
\hline
\end{tabular}

Note: $* * * * *$ and $*$ indicates significance level at $1 \%, 5 \%$ and $10 \%$ respectively.

The equation of the error correction model of the estimated ARDL $(1,0,0,0,1,0)$ is given as follows:

$$
\begin{gathered}
\Delta \ln G D P_{t}=0.0445 \Delta \ln G F C F_{t}+1.4544 \Delta \ln P O P_{t}-0.0041 \Delta F D I_{t}+0.0002 \Delta F I N_{t}+0.0008 \Delta T R A D E_{t}- \\
0.8223 E C T_{t-1}
\end{gathered}
$$

Table 8 shows the short-run model and its coefficients along with the error correction term. The population is found to be significant at $1 \%$ and trade is found to be significant at $10 \%$. The short-run elasticities of GFCF and POP are $0.04 \%$ and $1.45 \%$ respectively. The error correction term is defined as the speed of adjustment which verifies that the short-run disequilibrium relationship returns to the longrun equilibrium given that the coefficient is negative and significant. The ECT coefficient is -0.8223 which is negative and highly significant at a $1 \%$ level of significance. This confirms the existence of long-run relationships among the variables and also shows that the disequilibrium from the shock of the previous year converges back to the long-run equilibrium at the speed of $82.23 \%$ per annum. 


\section{Test Statistics}

$\begin{array}{cc}\text { Serial Correlation } & \mathrm{F}(1,29)=0.9778[.331] \\ \text { Functional Form } & \mathrm{F}(1,29)=2.9487[.097] \\ \text { Normality } & \mathrm{J}-\mathrm{B}=4.1487[0.126] \\ \text { Heteroscedasticity } & \mathrm{F}(1,36)=3.2035[.082]\end{array}$

The diagnostics tests reveal that there is no serial correlation and there is no misspecification in the model. The null hypothesis of normality and homoscedasticity also cannot be rejected as indicated by the critical values at a 5\% level of significance. Thus, the ARDL model passes all the diagnostic tests.

\section{TY Granger Non-Causality Test}

The Toda \& Yamamoto (1995) causality test is used to check the robustness and the direction of causality. The first step in this test is to determine the maximum order of the integration $\left(d_{\max }\right)$ of the time series. The unit root tests suggest the maximum order of $1\left(d_{\max }=1\right)$ in the time series. Secondly, lag length $(p)$ using various criteria is selected as shown in table 5. Finally, the VAR model is estimated using the lag length of $d_{\max }+p$. Therefore, the TY test is valid even if the order of integration of time series is more than 1. In this paper, lag length as per the SC criteria is chosen $(p=1)$ and VAR was estimated with a lag length of 2 i.e., $\left(d_{\max }+p\right)=2$ since this model showed no serial correlation. Moreover, the AR roots table showed that all the values lied within the circle which confirmed the stability and robustness of the VAR (2) model.

Table 10: Granger Causality Test Results

\begin{tabular}{lcccccc}
\hline Dependent Variables & InGDP & InGFCF & InPOP & FDI & FIN & TRADE \\
\hline $\operatorname{lnGDP}$ & - & 0.45 & 0.64 & $9.38 * * *$ & $11.95 * * *$ & 1.67 \\
$\operatorname{lnGFCF}$ & $41.76^{* * *}$ & - & $12.66^{* * *}$ & 1.75 & 2.17 & $9.74 * * *$ \\
$\ln \mathrm{FOP}$ & $40.97 * * *$ & 0.84 & - & $14.69 * * *$ & $12.79 * * *$ & 1.57 \\
FDI & $16.84 * * *$ & 0.29 & 3.96 & - & 3.18 & 2.73 \\
FIN & $28.54 * * *$ & 1.19 & 4.24 & $6.53 * *$ & - & 0.02 \\
TRADE & $24.02 * * *$ & $9.31 * * *$ & $5.56 *$ & 2.93 & 1.9 & - \\
\hline
\end{tabular}

Note: $* * *, * *$ and $*$ indicates significance level at $1 \%, 5 \%$ and $10 \%$ respectively.

Table 10 shows the chi-square values for Granger causality among the variables. The results show that lnGFCF, lnPOP, FDI, FIN and TRADE granger cause $\operatorname{lnGDP}$ at a $1 \%$ level of significance. This result satisfies the endogenous growth theory which states that national output is the function of capital, labor and technological factors. Another interesting result is that there is unidirectional granger causality from financial development to FDI which implies that FDI can be attracted in Nepal via the development of financial institutions and financial systems in Nepal. Also, there is bidirectional causality between capital investments and trade indicating that an increase in producer's investments further increases international trade activities and vice-versa.

\section{Sensitivity \& Stability Test}

CUSUM and CUSUMQ tests are carried out in order to test the stability of the model. Although these tests were designed for the identification of structural breaks that don't require the prior knowledge of the breaks like Chow tests, they are used widely by the researchers in order to check for the stability of the regression model (Turner, 2010). The CUSUM test calculates the cumulative sum of the recursive residuals of the model and plots them against the upper and lower bounds of the $95 \%$ confidence interval. 
If the plots of the residuals lie within the $5 \%$ critical bounds, the null hypothesis of the constancy of the coefficients is not rejected. However, if the plot crosses the $5 \%$ critical bound bands, the null hypothesis of parameter constancy is rejected and the model is deemed to be unstable. Similarly, the CUSUMQ test follows a similar procedure which plots the square of the residuals within the $5 \%$ band. For the stability of the VAR model, the plot of inverse roots of AR characteristic polynomial is examined.

\section{Figure 2: Stability Tests, Actual and Fitted Values, AR Roots}
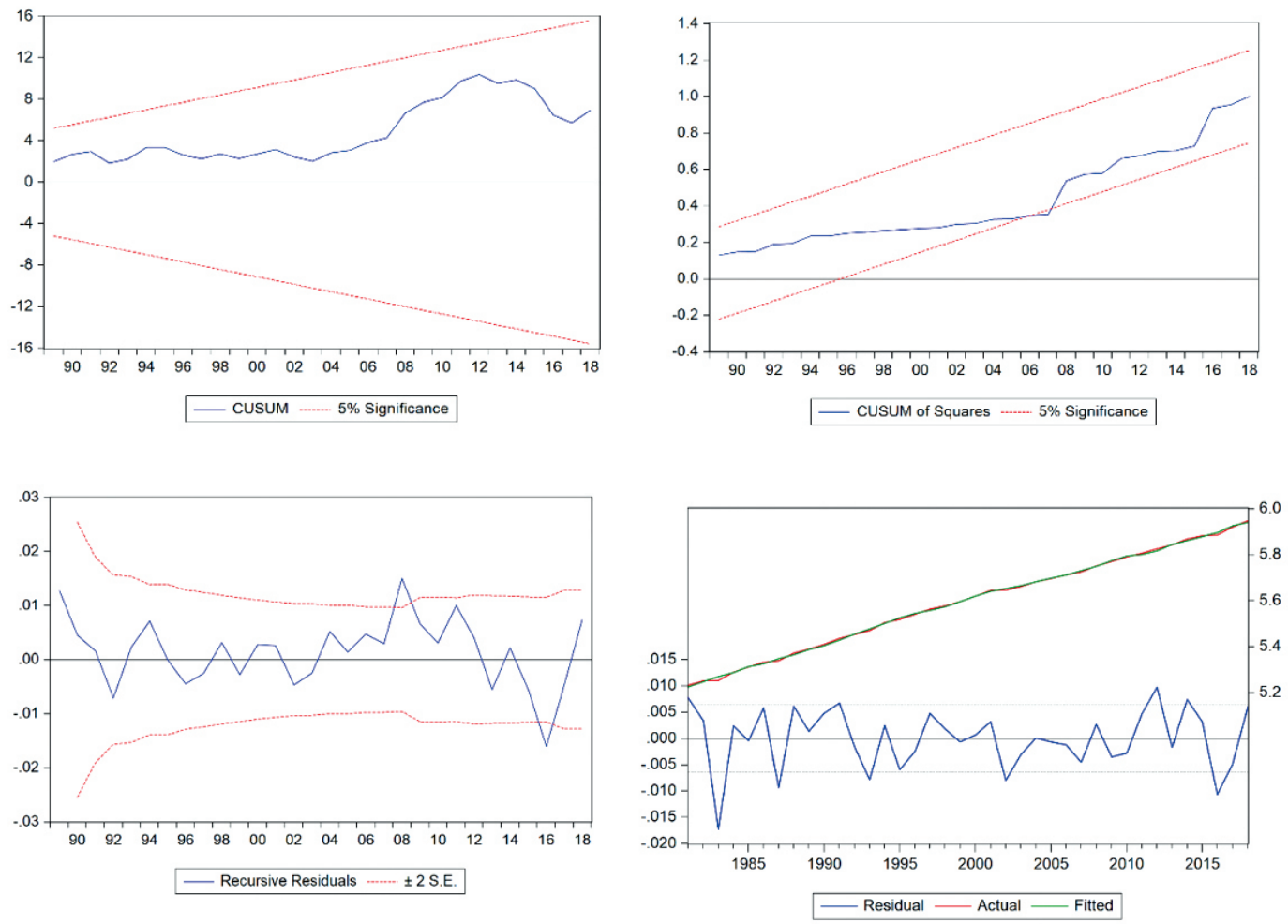

Inverse Roots of AR Characteristic Polynomial

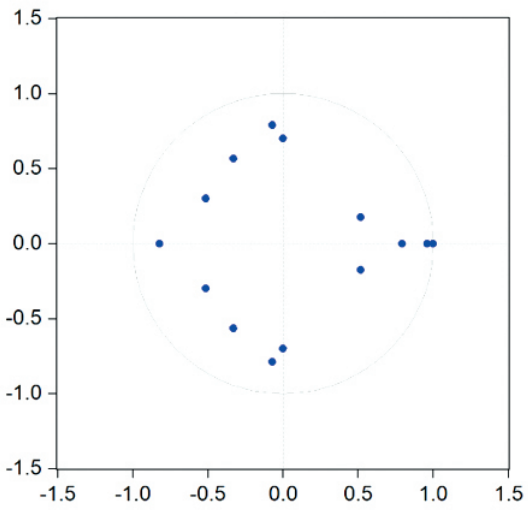


Figure 2 shows the plot of CUSUM, CUSUMQ, actual, fitted, residual values and inverse roots of AR characteristic polynomial. The CUSUM statistics fall inside the $5 \%$ confidence interval which shows the constancy of the parameters. The plot of CUSUMQ shows a little structural break but overall, the plots lie well within the $5 \%$ bound. The null hypothesis of coefficient constancy cannot be rejected. Therefore, the coefficients are stable. The graphs of actual, fitted and residuals indicate that the model is stationary. The estimated VAR(2) model is also stable and well-behaved as shown by the inverse roots of AR polynomial which lie within the circle. This confirms that the estimated ARDL and VAR model are stationary processes and they are stable overall.

\section{Conclusion}

Technological factors are considered to be prominent in inducing growth in an economy under endogenous growth theory. The theory is of even greater significance in the case of developing countries since these factors allow a country to bring in technology and ideas from other countries as argued by Romer (1986) because it leads to increasing returns to scale in terms of growth. Also, such factors have spillover effects that can further enhance the growth of an economy. The research study strived to examine the relationship between economic growth, capital, population, FDI, trade openness and financial development of Nepal under endogenous growth model framework. It was found that gross fixed capital formation, population and financial development were highly significant factors that influence the economic growth of the country positively in the long run. Out of the three technological factors incorporated in the study, financial development was found to impact the economic growth of Nepal positively. Whereas, FDI stock in flows to GDP ratio were found to negatively influence the economic growth of the country in the long run. Trade openness was not found to be significant. These results showed that Nepal hasn't been able to benefit from trade and FDI flows. This is because Nepal hasn't been able to attract enough foreign investment due to unfavorable laws, political instability and lack of proper infrastructure. Moreover, there is not enough value added to the GDP of Nepal from trade. The annual export of the country is very low as compared to the imports.

The above findings generate important policy implications for the policy makers of the country. Firstly, capital investments should be increased in the country through necessary fiscal and monetary policies since Nepal lacks adequate investments, especially in the manufacturing sector. Capital formation is bound to induce economic growth in both the long run and short run. Secondly, the development of human capital can act as a productivity factor that can further increase the productivity of the labor force of the country. Financial development should be boosted and monetary policies such as a reduction in borrowing interest rate, liquidity premiums to investors et cetera should be enforced as it allows investors to manage capital easily and further take part in the economic activities. Similarly, policies in favor of the development of infrastructure, reduction in tariffs, taxes and building lenient processes for operations of MNCs should be formulated to attract more FDI in Nepal. Lastly, exports should be promoted and Nepal should furthermore participate in global value chains in order to boost value addition in the economic growth from trade sectors. The import dependency should not restrict the country from domestically produced goods and services. Thus, enhancing the technological factors can further induce economic growth in Nepal.

\section{Conflict of Interest}

The author declares no conflict of interest.

\section{References}

Acaravci, A. (2010). FDI, trade and growth in Turkey: Evidence from ARDL bounds testing appraoch. Argumenta Oeconomica, 95-115. 
Ahmad, N., Hayat, M. F., Luqman, M., \& Ullah, S. (2012). The causal links between foreign direct investment and economic growth in Pakistan. European Journal of Business and Economics, 20-21.

Alezzee, I. H. (2014). Aggregate production function, its determinants and their impacts on aggregate output: Case of Bahrain. Journal of International Business and Economics, 125-147.

Apergis , N., Lyroudi , K., \& Vamvakidis, A. (2008). The relationship between foreign direct investment and economic growth: Evidence from transition countries. Transition Studies Review, 37-51.

Asian Development Bank. (2003). Country Economic Review. Kathmandu: Asian Development Bank.

Bhatt, S. R., \& Sharma, P. (2006). Trade liberalization and poverty: The Case of Nepal. Trade Insight, 24-26.

Bista, J. P., \& Bista, N. B. (2018). Finance-growth nexus in Nepal: An application of the ARDL approach in the presence of structural breaks. The Journal for Decision Makers, 236-249.

Bista, R. B. (2017). Economic liberalization in Nepal: Determinants, structure, and trends of FDI. The Winners Journal, 33-41.

Cobb, C. W., \& Douglas, P. H. (1928). A theory of production. The American Economic Review, 139-165.

Domar, E.D. (1946). Capital expansion, rate of growth, and employment. Econometrica, 137-147.

Dritsaki, M., Dritsaki, C., \& Adamopoulos, A. (2004). A causal relationship between trade, foreign direct investment and economic growth for Greece. American Journal of Applied Sciences, 230-235.

Elliot, A., \& Kulkarni, K. G. (2006). Role of FDI in the economic development of Nepal. The ICFAI Journal of Applied Economics, 33-47.

Engle, F. R., \& Granger, C. J. (1987). Co-integration and error correction: Representation, estimation, and testing. Econometrica, 251-276.

Granger, C. (1981). Some properties of time series data and their use in econometric model specification. Journal of Econometrics, 121-130.

Granger, C., \& Newbold, P. (1986). Forecasting Economic Time Series. London: Academic Press, Inc. Ltd.

Gurusamy, J., \& Anbu, S. (2010). A causal relationship between trade, foreign direct investment and economic growth for India. International Research Journal of Finance and Economics, 74-88.

Harrod, R. F. (1939). An essay in dynamic theory. The Economic Journal, 14-33.

Herzer, D., Lehmann, N., \& Siliverstovs, B. (2006). Export-led growth in chile: assessing the role of export composition in productivity growth. The Developing Economies, 306-328.

Johansen, S. (1988). Statistical analysis of cointegration vectors. Journal of Economic Dynamics and Control, 231-254.

Lucas, R. (1988). On the mechanics of economic development. Journal of Monetary Economics, 3-42.

M.B.(2014). The relationship between Trade, FDI and Economic growth in Tunisia: An application of autoregressive distributed lag model. Erriadh 4023 Sousse Tunisia: Faculty of Economics and Management of Sousse, University of Sousse.

Magnus, J., Frimpong, Abayie, O., \& Fosu, E. (2006). Bounds testing approach: an examination of foreign direct investment, trade, and growth relationships. American Journal of Applied Sciences, 2079-2085.

Majagaiya, Pokhrel, K., \& Yan, X. (2011). Relationship between foreign direct investment and economic growth case study of Nepal. International Journal of Business and Management, 242-246.

Mehic, E., Silajdzic, S., \& Hodovic, V. B. (2014). The impact of fdi on economic growth: some evidence from Southeast Europe. Emerging Markets Finance and Trade, 5-20.

Montalbano, P. (2011). Trade openness and developing countries' vulnerability: concepts, misconceptions, and directions for research. World Development, 1489-1502.

National Planning Commission. (2017). Demographic Changes of Nepal: Trends and Policy Implications. Kathmandu: Government of Nepal.

Nepal Rastra Bank. (2018). A Survey Report on Foreign Direct Investment in Nepal. Kathmandu: NRB Research Department.

Nepal Rastra Bank. (2020, April). Quaterly Economic Bulletin. Kathmandu: Nepal Rastra Bank. 
Nepal, R., \& Paija, N. (2019). Energy security, electricity, population and economic growth: The case of a developing South Asian resource-rich economy. Energy Policy, 771-781.

Nkoro, E., \& Uko, A. K. (2016). Autoregressive Distributed Lag (ARDL) cointegration technique: application and interpretation. Journal of Statistical and Econometric Methods, 63-91.

Odhiambo, N. M. (2007). Supply-leading versus demand-following hypothesis: Empirical evidence from three SSA Countries. African Development Review, 257-280.

Orhunbilge, A. N. (2014). Manufacturing Output in Romania: an ARDL Approach. Mediterranean Journal of Social Sciences, 342-353.

Pant, B. (2005). Nepal's trade sector: Review, repercussions and recommendations. NRB Economic Review, 89115.

Paudel, U., \& Khatri, U. (2018). Financial development and economic growth in Nepal: New intuitions from a time series causality method. Journal of Social Sciences, 116-123.

Pegkas, P. (2015). The impact of FDI on economic growth in Eurozone countries. The Journal of Economic Asymmetries, 124-132.

Perron, P. (1989). The great crash, the oil price shock, and the unit root hypothesis. Econometrica, 1361-1401.

Pesaran, M. H., \& Shin, Y. (1997). An autoregressive distributed lag modelling approach to cointegration analysis. Econometric Society Monographs, 371-413.

Romer, P. M. (1986). Increasing returns and long-run growth. The Quarterly Journal of Economics, 1002-1037.

Shin, Y., J., R. S., \& Pesaran, M. H. (2001). Bounds testing approaches to the analysis of level relationships. Journal Of Applied Econometrics, 289-326.

Shrestha, P. K. (2017). Economic liberalization in Nepal: Evaluating the changes in economic structure, employment and productivity. Journal of Development Innovations, 60-83.

Solow, R. M. (1956). A contribution to the theory of economic growth. The Quarterly Journal of Economics, 6594.

Swan, T.W. (1956). Economic growth and capital accumulation. Economic Record, 334-361.

Szkorupová, Z. (2014). A causal relationship between foreign direct investment, economic growth and export for Slovakia. Procedia Economics and Finance, 123-128.

Toda, H. Y., \& Yamamoto, T. (1995). Statistical inference in vector autoregressions with possibly integrated processes. Journal of Econometrics, 225-250.

Turner, P. (2010). Power properties of the CUSUM and CUSUMSQ tests for parameter instability. Applied Economics Letters, 1049-1053.

United Nations Conference on Trade and Development. (2019). Foreign direct investment: Inward and outward flows and stock, annual. Retrieved from UNCTADSTAT: https://unctadstat.unctad.org/wds/TableViewer/ tableView.aspx

World Bank. (2014). Nepal Economic Update. Washington : World Bank Group.

World Bank. (2019). Gross Fixed Capital Formation (\% of GDP). Retrieved from World Development Indicators: https://data.worldbank.org/indicator/NE.GDI.FTOT.ZS?locations=NP

World Bank. (2019). Trade (\% of GDP). Retrieved from World Development Indicators: https://data.worldbank. org/indicator/NE.TRD.GNFS.ZS

Zebregs, H. (1998). Can the neoclassical model explain the distribution of foreign direct investment across developing countries? Working Paper of the International Monetary Fund, 1-28.

Zivot, E., \& Andrews, D. W. (1992). Further evidence on the great crash, the oil-price shock, and the unit-root hypothesis. Journal of Business \& Economic Statistics, 251-270. 